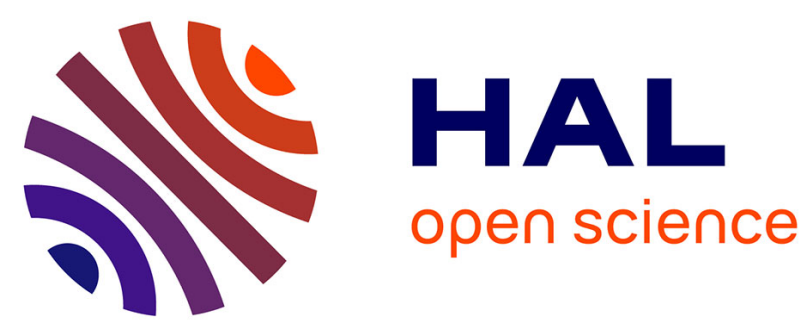

\title{
Perceptions, attitudes, and practices of French junior physicians regarding antibiotic use and resistance
}

\author{
C. Lévin, N. Thilly, M. Dousak, G. Beraud, M. Klesnik, S. Uhan, D.
}

Nathwani, B. Beovic, C. Pulcini

\section{- To cite this version:}

C. Lévin, N. Thilly, M. Dousak, G. Beraud, M. Klesnik, et al.. Perceptions, attitudes, and practices of French junior physicians regarding antibiotic use and resistance. Médecine et Maladies Infectieuses, 2019, 49 (4), pp.241-249. 10.1016/j.medmal.2018.09.003 . hal-02360025

\section{HAL Id: hal-02360025 \\ https://hal.univ-lorraine.fr/hal-02360025}

Submitted on 22 Oct 2021

HAL is a multi-disciplinary open access archive for the deposit and dissemination of scientific research documents, whether they are published or not. The documents may come from teaching and research institutions in France or abroad, or from public or private research centers.
L'archive ouverte pluridisciplinaire HAL, est destinée au dépôt et à la diffusion de documents scientifiques de niveau recherche, publiés ou non, émanant des établissements d'enseignement et de recherche français ou étrangers, des laboratoires publics ou privés.

\section{(ㄷ)(1) $\$$}

Distributed under a Creative Commons Attribution - NonCommerciall 4.0 International 


\title{
Perceptions, attitudes, and practices of French junior physicians regarding antibiotic use and resistance
}

\section{Perceptions, attitudes et pratiques des internes en médecine français concernant les prescriptions antibiotiques et l'antibiorésistance}

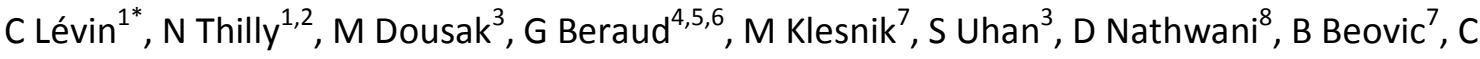 \\ Pulcini $^{1,9}$, on behalf of ESGAP (the ESCMID [European Society of Clinical Microbiology, \\ Infectious Diseases] Study Group for Antimicrobial stewardshiP)
}

1. Université de Lorraine, APEMAC, F-54000 Nancy, France

2. Plateforme d'Aide à la Recherche Clinique, Centre Hospitalier Universitaire de Nancy, Nancy, France

3. Faculty of Social Sciences, University of Ljubljana, Slovenia

4. Santé des populations et pratiques optimales en santé, Centre de recherche du CHU de Québec-Université Laval, Hôpital Saint-Sacrement, Québec, QC, Canada

5. Service de Médecine Interne et Maladies Infectieuses, Centre Hospitalier Universitaire de Poitiers, Poitiers, France 6. Censtat, Interuniversity Institute for Biostatistics and statistical Bioinformatics, Hasselt University, Hasselt, Belgique

7. Department of Infectious Disease, University Medical Centre, Ljubljana, Slovenia

8. Infection Unit, Ninewells Hospital and Medical School, Dundee, United Kingdom

9. Université de Lorraine, CHRU-Nancy, Service de Maladies Infectieuses et Tropicales, F54000 Nancy, France

\section{* Corresponding author}

Cécile Lévin. levincecile@gmail.com

Faculté de médecine de Nancy . EA 4360 APEMAC

9 avenue de la forêt de Haye

BP 20199

54505 Vandoeuvre lès Nancy Cedex

France 


\section{Declaration of interests}

The authors declare no competing interests.

Funding: none.

\section{Contribution of authors}

C. Levin analyzed the data and wrote the article. N. Thilly contributed to analyzing the data and wrote the article. M. Dousak designed the study and reviewed the article. G. Beraud contributed to data collection and reviewed the article. M. Klesnik designed the study. S. Uhan designed the study and reviewed the article. D. Nathwani designed the study and contributed to data collection. B. Beovic designed the study, coordinated the collection of data, and reviewed the article. C. Pulcini designed the study, coordinated the collection of data, and wrote the article.

Keywords: antibiotic prescription; antibiotic stewardship; junior physicians; survey

Mots clés : bon usage, enquête, praticien junior, prescription antibiotique 


\section{Abstract}

Objectives. To assess the perceptions, attitudes, and practices of French junior physicians regarding antibiotic use and resistance, and then to identify the characteristics of junior physicians associated with appropriate practices of antibiotic use.

Method. European junior physicians received an email invitation to complete a 49-item web questionnaire between September 2015 and January 2016. We present the French data. Multivariate regression models were used to identify the characteristics of junior physicians associated with appropriate prescription practices and with consideration of the antibiotic prescription consequences.

Results. The questionnaire was completed by 641 junior physicians: family medicine (37\%), other medical specialties (e.g., pediatrics, internal medicine, neurology: 45\%), surgical specialties (11\%), and anesthesiology-intensive care specialty (7\%). Most respondents (93\%) declared being aware of the risk of bacterial resistance and $41 \%$ acknowledged prescribing antibiotics more often than necessary. Two factors were independently associated with appropriate prescription practices: a high perceived level of education on antibiotic use $(\mathrm{OR}=1.51 ; 95 \% \mathrm{Cl}$ [1.01-2.30]) and a medical specialty (OR=1.69; 95\% Cl [1.16-2.46]). Factors independently associated with taking into account adverse events of antibiotics were a good perceived knowledge of antibiotics (OR=3.71; 95\% Cl [2.09-6.61]), and a high perceived education level on antibiotics (OR=1.70; 95\% $\mathrm{Cl}$ [1.11-2.58]).

Conclusion. Our data can help better define interventions targeting junior physicians in antibiotic stewardship programs. 


\section{RÉSUMÉ}

Objectifs. Évaluer les perceptions, attitudes et pratiques des internes en médecine concernant les prescriptions antibiotiques et l'antibiorésistance. Identifier les facteurs associés aux bonnes pratiques de prescriptions antibiotiques.

Méthode. Les internes en médecine européens ont été invités par email à remplir un questionnaire en ligne (49 items) entre septembre 2015 et janvier 2016. Nous présentons les données françaises. Des modèles de régression logistique multivariés ont été utilisés pour identifier les facteurs associés au suivi des recommandations de bon usage et à la prise en compte des effets secondaires des antibiotiques.

Résultats. Le questionnaire a été rempli par 641 internes: médecine générale (37\%), spécialités médicales (pédiatrie, médecine interne, neurologie : $45 \%$ ), chirurgicales (11\%) et anesthésie-réanimation (7\%). La majorité (93\%) disait être conscient du risque d'émergence de résistance bactérienne et $41 \%$ affirmaient trop prescrire d'antibiotiques. Deux facteurs étaient associés aux bonnes pratiques de suivi des recommandations : un niveau perçu de formation élevé en antibiothérapie (OR=1,51; IC $95 \%[1,01-2,30])$, l'exercice d'une spécialité médicale (OR=1,69; IC $95 \%$ [1,16-2,46]). Les facteurs associés à la prise en compte des effets secondaires des antibiotiques étaient un bon niveau déclaré de connaissances en antibiothérapie $(\mathrm{OR}=3,71$; IC $95 \%[2,09-6,61])$ et un bon niveau déclaré de formation en antibiothérapie (OR=1,70 ; IC $95 \%[1,11-2,58])$.

Conclusion. Ces données peuvent aider à mieux définir les interventions ciblant les internes dans les programmes de bon usage des antibiotiques. 


\section{INTRODUCTION}

Antibiotics are prescribed by almost all physicians. Bacterial resistance has become a major global health problem [1-3]. In spite of the well-known relation between antibiotic use and the development of bacterial resistance, antibiotic consumption varies substantially from one country to another. Approximately half of antibiotic prescriptions are either unnecessary or inappropriate in France [4,5], which is still one of the biggest antibiotic consumers in Europe [6]. A national antibiotic plan was implemented in 2001 [7], but few results have been observed so far.

During their undergraduate studies, medical students receive education on antibiotics. Studies have shown that they feel confident about diagnosing infections, but report gaps in knowledge regarding how best to decide on the choice of antibiotics, the dose, the frequency of administration, the duration of treatment, and combination therapies $[8,9]$. A survey of French medical students [10] also showed that they were aware that antibiotic resistance was a current and growing problem but training on antibiotics and antibiotic stewardship was considered insufficient. Several studies assessed the medical students' perception of antibiotic use and resistance $[8,11,12]$, but few focused on junior physicians, i.e. physicians in training for their specialty during the postgraduate period. To the best of our knowledge only one such study was performed in one medical school in France in 2008 [4].

During their postgraduate training, junior physicians start prescribing antibiotics on their own in most European countries. Our main objective was therefore to assess the perceptions, attitudes, and practices of junior physicians regarding antibiotic use and resistance in France in 2016. The secondary objective was to identify the personal and 
professional characteristics of junior physicians associated with appropriate practices concerning antibiotic prescription and adverse events.

\section{MATERIAL AND METHODS}

Survey design and setting

We conducted an exploratory nationwide cross-sectional questionnaire survey, from September 2015 to January 2016. This survey was part of a larger European study called YPAR (Young doctors' perspectives on antimicrobial use and resistance in Europe) coordinated by ESGAP (the ESCMID [European Society of Clinical Microbiology and Infectious Diseases] Study Group for Antimicrobial stewardshiP). Reporting of methods and results comply with published reporting guidelines for surveys $[13,14]$.

\section{Participants}

The questionnaire targeted all junior physicians prescribing antibiotics. Non-prescribers such as public health, occupational medicine, biology and pathology junior physicians, were excluded after answering a first filtering question on their daily contacts with patients.

In France, junior physicians are medical students who have passed the national exam at the end of their $6^{\text {th }}$ year of undergraduate studies to start their residency (postgraduate specialty training period). The duration of the residency depends on the chosen specialty, and ranges between three and five years.

The survey participation was voluntary and not compensated. As the questionnaire was anonymous and no information on the health of respondents was collected, ethical approval was not required. 


\section{Questionnaire survey}

The questionnaire was designed by a multidisciplinary panel of experts (infectious disease specialists and sociologists) after a literature review of comparable studies conducted among medical students, and junior and senior physicians $[4,15,16]$.

Ten medical students in France and in Slovenia tested the first draft of the questionnaire to check for clarity and conciseness.

The 49-item self-administered final questionnaire was in English (available from the authors upon request) and hosted on an Internet survey platform (One Click Survey ${ }^{\circledR}$ - an open source survey tool, Ljubljana). Of the 49 items, 20 focused on attitudes and practices, 21 on the perceptions of antibiotics, resistance, and education on these topics, and eight items aimed to collect socio-demographic data to characterize our respondent sample.

We pooled medical specialties into four groups: family medicine; other medical specialties including cardiology and vascular medicine, dermatology-venereology, emergency medicine, endocrinology, diabetology, gastroenterology, geriatrics, hematology, infectious diseases, medical oncology, nephrology, neurology, pediatrics, pneumology, rheumatology, tropical medicine; surgical specialties: cardio-thoracic surgery, cardiovascular surgery, abdominal surgery, general surgery, gynecology and obstetrics, maxillofacial surgery, urology surgery, neurosurgery, ophthalmology, orthopedics, otorhinolaryngology, plastic surgery, thoracic surgery; anesthesiology-intensive care medicine (see questionnaire available upon request; Q23 - Specialty).

\section{Survey distribution}


Members of the French infectious diseases society (French acronym SPILF) mailing-list Infectioflash ${ }^{\circledR}$ received an email from the national coordinator (Prof. Céline Pulcini for France) asking them to transfer the invitation email to their junior physicians. A reminder email was sent two months later.

\section{Indicators of appropriate practices}

We used items about perceptions, attitudes, and practices to build two composite indicators of "appropriate practices". We then identified the characteristics of respondents associated with these two indicators.

The first indicator, called "appropriate practices concerning antibiotic prescription", combined the following five items: (i) I tend to follow local policy/guidance, (ii) for patients receiving parenteral treatment, I always try to switch to an oral therapy, (iii) physicians prescribe antibiotics more often than necessary, (iv) as some antibiotics need approval by another physician, I try to avoid prescribing them and I prescribe other antibiotics instead, (v) I choose an antibiotic that I feel comfortable with. The answer "agree/agree strongly" was considered the correct answer for the first three items and the answer "disagree/disagree strongly" was considered the correct answer for the last two items. Respondents who answered correctly to at least four of the five items were considered as having appropriate practices concerning antibiotic prescription.

The second composite indicator, called "appropriate practices concerning adverse events of antibiotics" combined the following four items: (i) I keep in mind the potential emergence of bacterial resistance to antibiotics, (ii) I keep in mind the potential occurrence of $C$. difficile as a consequence of my antibiotic choice, (iii) I take into consideration the potential adverse effects of the antibiotic treatment, (iv) limiting the antibiotic treatment duration will help 
reduce the development of bacterial resistance. The answer "agree/agree strongly" was considered the correct answer for all four items. Respondents who answered correctly to all four items were considered as having appropriate practices concerning adverse events of antibiotics.

Respondents with missing data for at least one item were not considered.

\section{Knowledge and education level}

We also generated group of items to create two other composite indicators. The first composite indicator focused on the following theme: "Do I have the necessary knowledge?" (Q5 - see questionnaire available upon request) renamed “Perceived level of knowledge of antibiotics", which pooled all items of Q5 (six items), with Likert-scale replies 4 or 5 considered as good level of knowledge.

The second one focused on "Education" renamed "Perceived level of education on antibiotics" which included three items of Q16 (see questionnaire available upon request) (the last one about representatives of pharmaceutical companies was excluded), with Likertscale replies 3 or 4 considered as good level of education.

\section{Statistical analyses}

Descriptive statistics were used to assess the socio-demographic characteristics of our sample, the perceptions, attitudes, and practices of respondents on antibiotics and resistance. The results are presented as numbers and percentages.

A two-step analysis was then applied to identify the personal and professional characteristics of respondents associated with appropriate practices concerning antibiotic prescription and adverse events. Investigated characteristics were gender, year of 
specialization, specialty, frequency of antibiotic prescribing, perceived level of knowledge of antibiotics (six pooled items of Q5; see questionnaire available upon request), perceived level of education on antibiotics (three pooled items of Q16; see questionnaire available upon request), having their antibiotic prescriptions supervised by a senior physician, and declaring having a senior physician who usually comply with guidelines. Factors reaching the $P$ threshold of 0.20 in the bivariate logistic regression models were introduced in the multivariate logistic regression models. The significance $\alpha$ was set at 0.05 in a two-side test. Statistical analyses were performed using $\mathrm{SAS}^{\circledR}$ version 9.4 (SAS ${ }^{\circledR}$ Institute Inc, Cary, NC, USA).

\section{RESULTS}

Six hundred and forty-one eligible junior physicians participated in our survey. Characteristics of respondents are presented in Table 1. All medical schools except the one in Tours were represented (Figure 1).

\section{Antibiotic stewardship principles}

Figure 2 presents the perceptions, attitudes, and practices of junior physicians regarding antibiotic stewardship principles.

\section{Perception of the bacterial resistance problem}

Bacterial resistance to antibiotics was perceived as a global issue by $618 / 641$ participants (97\%). A large part $(92.5 \%, 590 / 638)$ considered it to be problematic in France but only $74 \%$ $(471 / 637)$ considered it a major problem in their own work place. 


\section{Decision-making process when prescribing antibiotics}

Figure 3 presents the junior physicians' perception of their knowledge regarding various steps of the antibiotic prescribing process and shows gaps in knowledge for approximately half of them. When calculating the global score "Self-reported knowledge of antibiotics", only $10 \%$ (65/640) reported good knowledge for all items.

The decision on whether or not to start an antibiotic treatment was mainly guided by how sick the patient was $(76.2 \%, 484 / 635)$ and whether he was immunodeficient $(97 \%, 616 / 635)$. Most junior physicians $(91.1 \%, 574 / 630)$ declared complying with local policy/guidance. Adverse events were taken into consideration in $85.5 \%$ (543/635) of cases when prescribing but the risk of Clostridium difficile infections was not taken into consideration when choosing the antibiotic in $30 \%(191 / 632)$ of cases.

In case of positive microbiology results, $95.5 \%(611 / 640)$ of respondents declared deescalating the antibiotic treatment if possible (i.e., switching to a narrower spectrum antibiotic). For patients initially started on parenteral treatment, 90\% (574/638) declared always trying to switch to an oral therapy.

\section{Prescribing etiquette}

Figure 2 presents some criteria of the prescribing etiquette, i.e. the implicit set of rules that prevails in any healthcare facility or department. Choosing an antibiotic was often reported as dependent of the prescribing patterns of the department where respondents worked $(77 \%, 487 / 632)$ and $73 \%(460 / 630)$ chose antibiotics they felt comfortable with.

Junior physicians declared prescribing antibiotics as per their senior physician's instructions in $60.7 \%$ of cases $(389 / 640)$ while $39.3 \%(251 / 640)$ prescribed antibiotics on their own. 
Evaluation of the compliance of senior physicians with guidelines showed that only $63.8 \%$ of junior physicians declared that their senior physicians complied with guidelines, others (36.1\%) chose an antibiotic according to their "personal experience".

Factors associated with appropriate practices concerning antibiotic prescription and adverse events

With regard to the first indicator of appropriate practice called "appropriate practices concerning antibiotic prescription", 35.5\% (217/612) of respondents had an appropriate practice versus $64.5 \%(395 / 612)$ of respondents with an inappropriate practice.

With regard to the second indicator called "appropriate practices concerning adverse events of antibiotics", $39.4 \%(245 / 621)$ of respondents had appropriate practices versus $60.6 \%$ (376/621) of respondents with an inappropriate practice.

The personal and professional characteristics of respondents independently associated with appropriate practices concerning antibiotic prescription were the specialty and the perceived level of education on antibiotics (Table 2). Appropriate practices were more often observed in junior physicians of medical specialties (OR=1.69, $95 \% \mathrm{Cl}[1.16-2.46]$ ) than in junior physicians of other specialties, and junior physicians with a high perceived level of education on antibiotics were 1.51 times (95\% Cl [1.01-2.30]) more likely to declare appropriate practices.

The personal and professional characteristics of respondents independently associated with appropriate practices concerning adverse events of antibiotic prescription were the perceived knowledge of antibiotics and the perceived level of education (Table 3). Junior physicians with a good perceived knowledge of antibiotics and those with a high perceived 
level of education were respectively 3.71 times $(95 \% \mathrm{Cl}[2.09-6.61])$ and 1.70 times $(95 \% \mathrm{Cl}$ [1.11-2.58]) more likely to declare appropriate practices regarding adverse events.

\section{DISCUSSION}

Our exploratory nationwide survey has identified gaps in knowledge of antibiotic prescribing and barriers to a responsible use of antibiotics, with the vast majority of junior physicians asking for further education on these topics. This is consistent with previous surveys conducted among French medical students. Dyar et al. [10] conducted a large survey in 2013 with medical students on knowledge, attitudes, and beliefs about antibiotic prescribing and resistance. The students declared feeling concerned about bacterial resistance to antibiotics as $94 \%$ believed resistance was a national problem but only $69 \%$ mentioned it as a problem in their hospital. Comparable results were observed in our study: although almost all respondents (92.5\%) viewed antibiotic resistance as a national problem, only $74 \%$ believed that resistance was a problem in their daily clinical practice. This is in line with previous surveys conducted among healthcare professionals (senior or in training) $[4,17]$.

The comparison between the study of French medical students [10] and our results highlights the absence of significant change after the start of residency as participants still asked for more training on antibiotic use.

We also underlined the importance of the "prescribing etiquette". Our survey showed that almost $90 \%$ of junior physicians noticed, during their postgraduate training when rotating through the various departments, that they each have their own prescribing habits in terms of antibiotic use (deciding on the start of the antibiotic treatment, choice of antibiotic, duration of treatment, etc.). Changing the use of antibiotics is a real challenge as many 
factors are at play [18]. We know that socio-demographic factors, previous clinical practice, university education, and medical specialty all influence the antibiotic prescribing process [19]. As highlighted in a recent systematic review about social and professional influences on antimicrobial prescribing for physicians-in-training [20], the context is often challenging in light of the hierarchy, roles and responsibilities, prescribing norms, and implicit expectations about knowledge [21-22]. Our current knowledge of the relative effect of each factor is limited, but we know that strategies aimed to improve antibiotic use (i.e., antibiotic stewardship programs) have to be multifaceted and must take into account the role of this "prescribing etiquette" to be efficient.

Our results also show that targeting junior (and senior) physicians within antibiotic stewardship programs is crucial. The set of possible interventions, ideally conducted by a multidisciplinary antibiotic stewardship team (including an infectious disease specialist, a pharmacist, and a microbiologist, if possible) is large: education, ward rounds, systematic advice for specific situations (broad-spectrum antibiotics, positive blood cultures, etc.), computerized decision-support systems, etc.. Medical students and junior physicians should also be encouraged by their supervisors to use guidelines when prescribing antibiotics.

Our exploratory survey provides much needed nationwide and updated French data as the only survey focusing on junior physicians was conducted in only one medical school in France in 2008 [4]. It has, however, several limitations. Our response rate was low (the total number of prescribing junior physicians in France being around 18,000), which may have induced a selection bias as received responses probably came from the most motivated and knowledgeable students. As with most surveys, respondents might have given socially 
desirable answers. We ensured complete respondent anonymity to minimize this potential bias.

\section{CONCLUSION}

We observed that most junior physicians (92.5\%) reported being aware that antibiotic resistance was a current and growing problem. Most of them (95\%) were asking for further training. This highlights the importance of antibiotic stewardship programs and the opportunity to bring changes to the training within the French residency reform that started in November 2017 [23,24]. 


\section{References}

[1] World Health Organization (WHO). Global Action Plan on Antimicrobial Resistance, 2015 [http://apps.who.int/iris/bitstream/10665/193736/1/9789241509763_eng.pdf_,_accessed August 27, 2017].

[2] WHO. Antimicrobial resistance : global report on surveillance. Geneva, 2014 [http://apps.who.int/iris/bitstream/10665/112642/1/9789241564748_eng.pdf, accessed August 26, 2017].

[3] Agence nationale de sécurité du médicament et des produits de santé. Consommation d'antibiotiques et résistances, Novembre 2016, Resistance Antibiotiques-nov2016-1.pdf

[4] Pulcini C, Williams F, Molinari N, Davey P, Nathwani D. Junior doctors' knowledge and perceptions of antibiotic resistance and prescribing: a survey in France and Scotland. Clin Microbiol Infect. 2011 Jan;17(1):80-7.

[5] Pulcini C, Cua E, Lieutier F, Landraud L, Dellamonica P, Roger PM. Antibiotic misuse: a prospective clinical audit in a French university hospital. Eur J Clin Microbiol Infect Dis. 2007 Apr 4;26(4):277-80.

[6] European Centre for Disease Prevention and Control (ECDC), European Food Safety Authority (EFSA), European Medicines Agency (EMA). ECDC/EFSA/EMA second joint report on the integrated analysis of the consumption of antimicrobial agents and occurrence of antimicrobial resistance in bacteria from humans and food-producing animals: Joint Interagency Antimicrobial Consumption and Resistance Analysis (JIACRA) Report. EFSA J 2017 [cited Jul 2017 Aug 25];15(7), [http://onlinelibrary.wiley.com/doi/10.2903/j.efsa.2017.4872/epdf , accessed August 25, 2017].

[7] Ministère chargé de la santé. Plan national d'alerte sur les antibiotiques 2011-2016, [http://solidarites-sante.gouv.fr/IMG/pdf/plan_antibiotiques_2011-2016_DEFINITIF.pdf, accessed August 25, 2017].

[8] Minen MT, Duquaine D, Marx MA, Weiss D. A survey of knowledge, attitudes, and beliefs of medical students concerning antimicrobial use and resistance. Microb Drug Resist Larchmt N. 2010 Dec;16(4):285-9.

[9] Pulcini C, Wencker F, Frimodt-Møller N, Kern WV, Nathwani D, Rodríguez-Baño J, et al. European survey on principles of prudent antibiotic prescribing teaching in undergraduate students. Clin Microbiol Infect Off Publ Eur Soc Clin Microbiol Infect Dis. 2015 Apr;21(4):35461.

[10] Dyar OJ, Howard P, Nathwani D, Pulcini C, ESGAP (the ESCMID [European Society of Clinical Microbiology, Infectious Diseases] Study Group for Antibiotic Policies). Knowledge, attitudes, and beliefs of French medical students about antibiotic prescribing and resistance. 
Med Mal Infect. 2013 Oct;43(10):423-30.

[11] Dyar OJ, Pulcini C, Howard P, Nathwani D, ESGAP (ESCMID Study Group for Antibiotic Policies). European medical students: a first multicentre study of knowledge, attitudes and perceptions of antibiotic prescribing and antibiotic resistance. J Antimicrob Chemother. 2014 Mar;69(3):842-6.

[12] Wright EP, Jain P. Survey of antibiotic knowledge amongst final year medical students. J Antimicrob Chemother. 2004 Mar;53(3):550-1.

[13] Pulcini C, Leibovici L, CMI Editorial Office. CMI guidance for authors of surveys. Clin Microbiol Infect Off Publ Eur Soc Clin Microbiol Infect Dis. 2016 Nov;22(11):901-2.

[14] Bennett C, Khangura S, Brehaut JC, Graham ID, Moher D, Potter BK, et al. Reporting guidelines for survey research: an analysis of published guidance and reporting practices. PLoS Med. 2010 Aug;8(8):e1001069.

[15] García C, Llamocca LP, García K, Jiménez A, Samalvides F, Gotuzzo E, et al. Knowledge, attitudes and practice survey about antimicrobial resistance and prescribing among physicians in a hospital setting in Lima, Peru. BMC Clin Pharmacol. 2011 Nov 15;11:18.

[16] Aggarwal S, Mathew J, Singh H, Sharma V. Attitude and perception of junior resident doctors' regarding antibiotic resistance - A pilot study. J Acute Dis. 2014;3(1):6-9.

[17] Pulcini C, Naqvi A, Gardella F, Dellamonica P, Sotto A. Résistance bactérienne et prescription antibiotique : perceptions, attitudes et connaissances d'un échantillon de médecins généralistes. Médecine Mal Infect. 2010 Dec;40(12):703-9.

[18] Trémolières F. Quels sont les déterminants des comportements des prescripteurs d'antibiotiques ? Médecine Mal Infect. 2003 Jan;33:73-85.

[19] Lopez-Vazquez P, Vazquez-Lago JM, Figueiras A. Misprescription of antibiotics in primary care: a critical systematic review of its determinants: Misprescription of antibiotics. J Eval Clin Pract. 2012 Apr;18(2):473-84.

[20] Papoutsi C, Mattick K, Pearson M, Brennan N, Briscoe S, Wong G. Social and professional influences on antimicrobial prescribing for doctors-in-training: a realist review. J Antimicrob Chemother. 2017 Sept;72(9):2418-30.

[21] Charani E, Castro-Sanchez E, Sevdalis N, Kyratsis $Y$, Drumright L, Shah N, et al. Understanding the determinants of antimicrobial prescribing within hospitals: the role of "prescribing etiquette." Clin Infect Dis Off Publ Infect Dis Soc Am. 2013 Jul;57(2):188-96.

[22] Teixeira Rodrigues A, Roque F, Falcão A, Figueiras A, Herdeiro MT. Understanding physician antibiotic prescribing behaviour: a systematic review of qualitative studies. Int $J$ Antimicrob Agents. 2013 Mar;41(3):203-12. 
[23] Ministère chargé de la santé. Arrêté du 12 avril 2017 portant organisation du troisième cycle des études de médecine, [https://www.legifrance.gouv.fr/affichTexte.do?cidTexte=JORFTEXT000034419758\&fastPos= 1\&fastReqld=1017406473, accessed August 25, 2017].

[24] Ministère chargé de la santé. Arrêté du 21 avril 2017 relatif aux connaissances, aux compétences et aux maquettes de formation des diplômes d'études spécialisées et fixant la liste de ces diplômes et des options et formations spécialisées transversales du troisième cycle des études de médecine, [https://www.legifrance.gouv.fr/affichTexte.do?cidTexte=JORFTEXT000034502881\&fastPos= 1\&fastReqld=278927322, accessed August 25, 2017]. 
Figure 1. Geographical distribution of respondents $(N=641)$

Figure 1. Répartition géographique des répondants ( $N=641)$

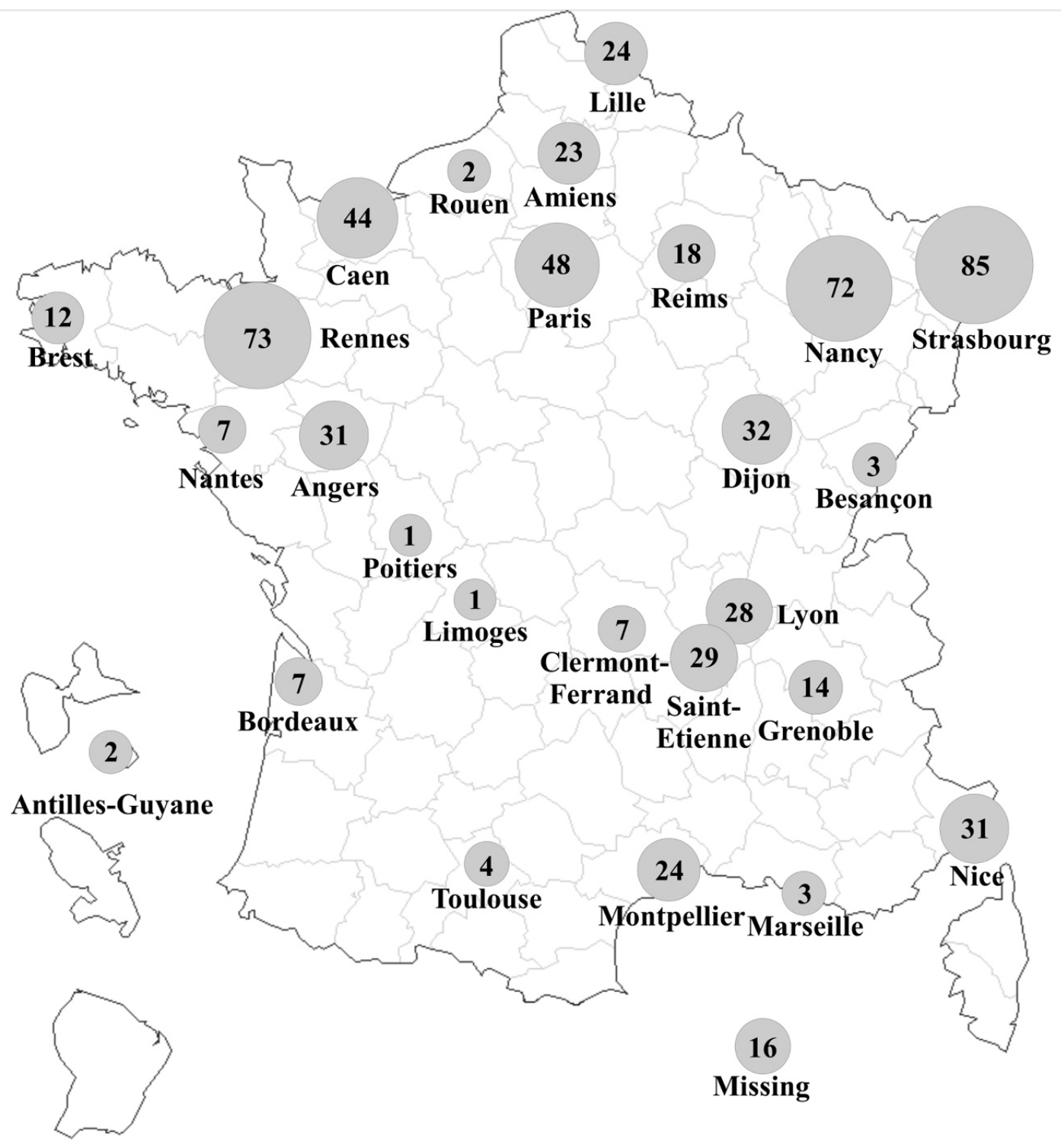


Figure 2. Perceptions, attitudes, and practices of junior physicians regarding antibiotic stewardship principles

Figure 2. Perceptions, attitudes et pratiques des internes concernant les principes de bon usage des antibiotiques

\section{Importance of appropriate prescribing of antibiotics}

I prescribe antibiotics more often than necessary $(n=639)$

Physicians prescribe antibiotics more often than necessary $(n=636)$

Unnecessary antibiotic treatments can be harmful for individual patient $(n=640)$

The inappropriate use of antibiotics greatly contributes to the development of bacterial resistance to antibiotics ( $n=639$ )

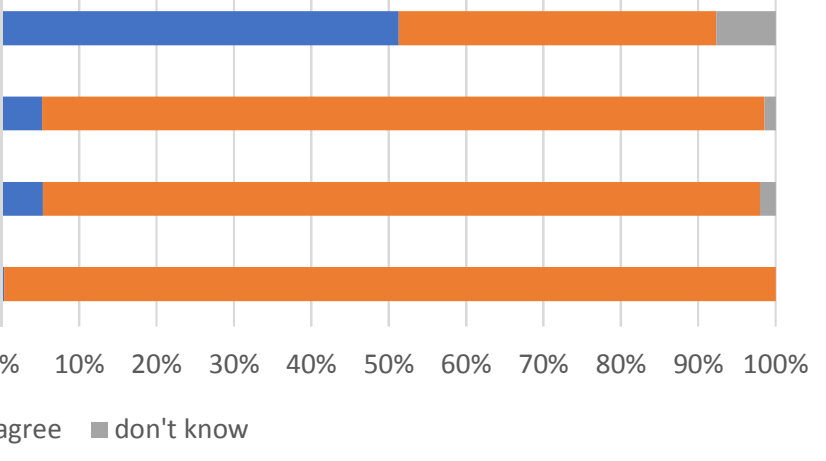

- disagree $\square$ agree $\square$ don't know

\section{Limiting antibiotic use}

Limiting the use of antibiotics is harmful for the patient $(n=638)$

Because some antibiotics need approval by another physician, I

try to avoid them and prescribe other antibiotics instead

$$
(n=638)
$$

Limiting the use of antibiotics will help reduce the development of bacterial resistance $(n=638)$

Limiting the duration of the antibiotic treatment will help reduce the development of bacterial resistance $(n=638)$

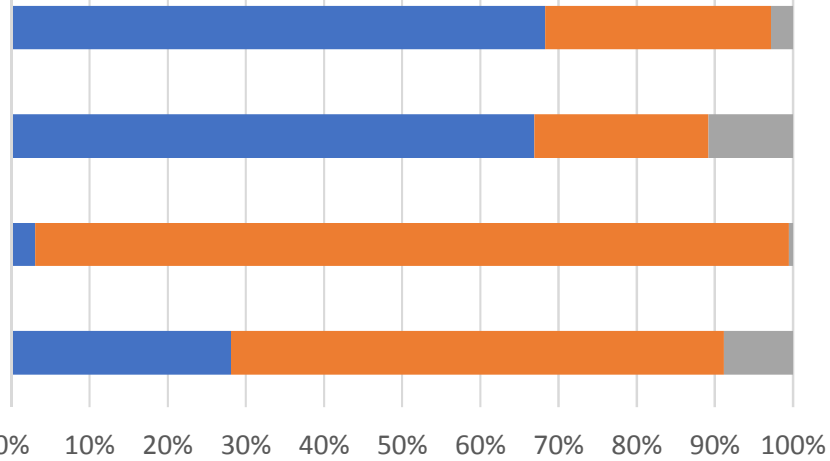

- disagree agree a don't know

\section{Prescribing patterns}

During my training programme, when rotating through different departments, I noticed that they each have their own "prescribing habits" as regards antibiotic use $(n=640)$

I noticed that some departments consider their patients "different"/"special"/"unique" and do not follow guidelines when prescribing antibiotics $(n=639)$

If I think that the decision of a colleague about an antibiotic treatment is inappropriate, I tend to share my opinion with them $(n=639)$

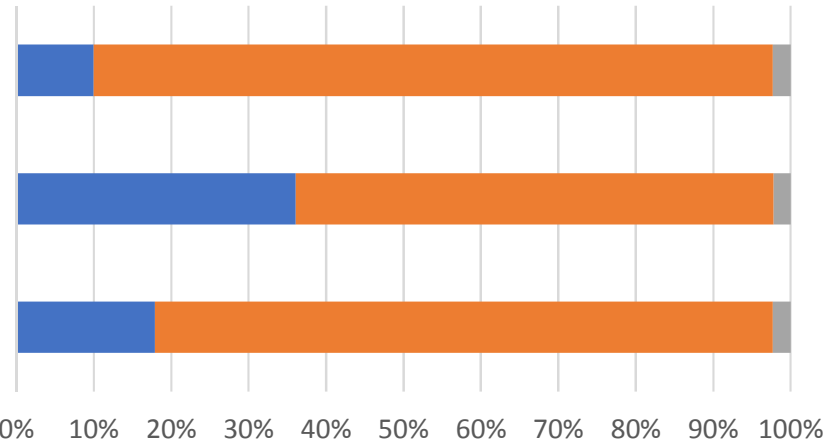

घisagree $\quad$ agree $\quad$ don't know 


\section{Education}

I believe that good knowledge of antibiotics is important for my work $(n=640)$

I am aware of the guidelines and recommendations for antibiotic use in the hospital where I work $(n=640)$

I wish to get more training/education on antibiotics $(n=638)$

I get a lot of information on antibiotics and their potential use from representatives of pharmaceutical companies $(n=639)$

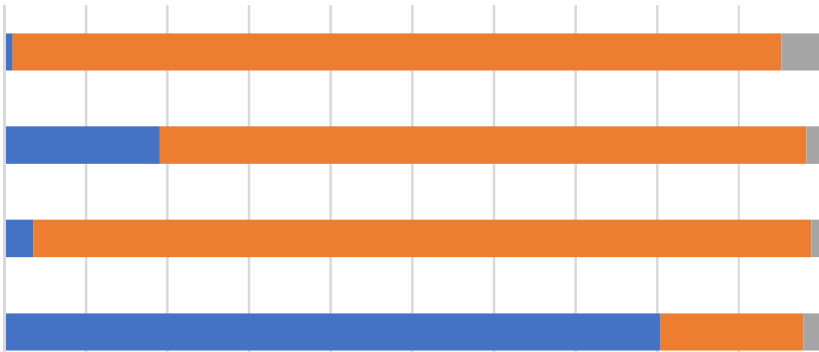

$\begin{array}{lllllllllll}0 \% & 10 \% & 20 \% & 30 \% & 40 \% & 50 \% & 60 \% & 70 \% & 80 \% & 90 \% & 100 \%\end{array}$

- disagree agree don't know 
Figure 3. Self-perception of junior physicians' knowledge of the various steps of the antibiotic prescribing process

Figure 3. Auto-perception des connaissances des internes en médecine concernant les différentes étapes du processus de prescription d'antibiotiques

\section{Do I have the necessary knowledge to:}

decide whether or not a patient needs an antibiotic treatment $(n=640)$

choose the most appropriate antibiotic $(n=638)$

decide on a proper dosage and dosing frequency of antibiotics $(n=638)$

decide on a proper duration of antibiotic treatment $(n=639)$

properly choose between parenteral and oral antibiotic treatment $(n=637)$

be able to adequately interpret microbiology results $(n=637)$

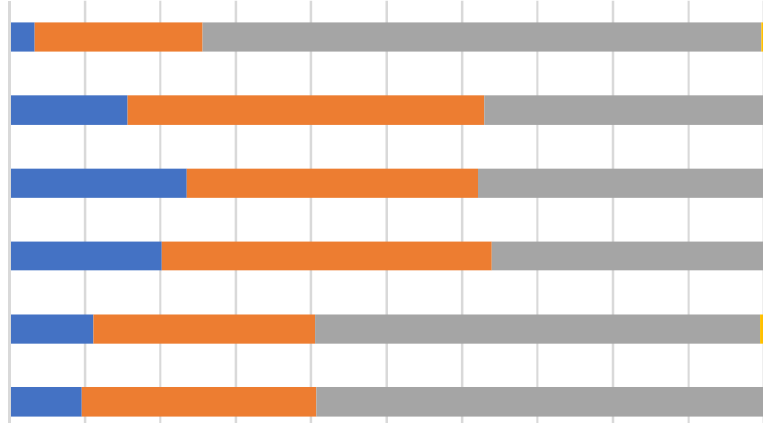

$\begin{array}{lllllllllll}0 \% & 10 \% & 20 \% & 30 \% & 40 \% & 50 \% & 60 \% & 70 \% & 80 \% & 90 \% & 100 \%\end{array}$

apoor $\square$ medium $\square$ good don't know 

Table 1. Characteristics of the survey respondents $(N=641)$

Tableau 1. Caractéristiques des répondants à l'enquête ( $N=641)$

\begin{tabular}{lll}
\hline & $\mathbf{n}$ & $\%$ \\
\hline Gender & 281 & 43.8 \\
Male & 360 & 56.2 \\
Female & & \\
Year of specialization & 115 & 17.9 \\
First year & 319 & 49.8 \\
Middle year(s) & 207 & 32.3 \\
Last year & 235 & \\
Specialty & 287 & 36.6 \\
General medicine & 73 & 44.8 \\
Other medical specialties & 46 & 11.4 \\
Surgical specialties & & 7.2 \\
Anesthesiology-intensive care & 328 & 51.2 \\
\hline Frequency of antibiotic prescribing & 313 & 48.8 \\
$\geq 1$ prescription(s)/day & & \\
$<1$ prescription/day & & \\
\hline
\end{tabular}


Table 2. Factors associated with appropriate practice concerning antibiotic prescriptions

Tableau 2. Facteurs associés aux bonnes pratiques concernant les prescriptions d'antibiotiques

$\begin{array}{llllll}\text { Appropriate } & \text { Inappropriate } & \text { Bivariate } & & \text { Multivariable } & \\ \text { practice } & \text { practice } & \text { regression } & & \text { regression } & \\ \mathrm{N}=217 & \mathrm{~N}=395(64.5 \%) & \text { OR }(95 \% \mathrm{Cl}) & p & \text { OR }(95 \% \mathrm{Cl}) & p \\ (35.5 \%) & \mathrm{n}(\%) & & & \\ \mathrm{n}(\%) & & & & \end{array}$

\begin{tabular}{|c|c|c|c|c|c|c|}
\hline Gender & & & & 0.90 & & \\
\hline Male & 95 (35.2) & $175(64.8)$ & 1 & & & \\
\hline Female & $122(35.7)$ & $220(64.3)$ & $1.02(0.73-1.43)$ & & & \\
\hline Year of specialization & & & & 0.46 & & \\
\hline First year & $34(31.8)$ & $73(68.2)$ & 1 & & & \\
\hline Middle year(s) & $116(37.8)$ & $191(62.2)$ & $1.30(0.82-2.08)$ & & & \\
\hline Last year & $68(34.0)$ & $132(66.0)$ & $1.11(0.67-1.83)$ & & & \\
\hline Specialty & & & & 0.06 & & 0.04 \\
\hline Family medicine & $67(30.2)$ & $154(69.7)$ & 1 & & 1 & \\
\hline Other medical specialties & $117(41.0)$ & $168(59.0)$ & $1.60(1.10-2.30)$ & & $1.69(1.16-2.46)$ & \\
\hline Surgical specialties & $18(30.0)$ & $42(70.0)$ & $0.98(0.53-1.83)$ & & $1.03(0.55-1.94)$ & \\
\hline Anesthesiology-intensive care & $15(32.6)$ & $31(67.4)$ & $1.11(0.56-2.20)$ & & $1.13(0.57-2.26)$ & \\
\hline $\begin{array}{l}\text { Frequency of antibiotic } \\
\text { prescribing }\end{array}$ & & & & 0.16 & & 0.15 \\
\hline$<1$ prescription/day & $97(32.7)$ & $200(67.3)$ & 1 & & 1 & \\
\hline$\geq 1$ prescription/day & $120(38.1)$ & $195(61.9)$ & $1.28(0.91-1.81)$ & & $1.35(0.96-1.89)$ & \\
\hline $\begin{array}{l}\text { Perceived knowledge of } \\
\text { antibiotics }\end{array}$ & & & & 0.07 & & 0.16 \\
\hline Poor & $188(34.2)$ & $361(65.8)$ & 1 & & 1 & \\
\hline Good & $29(46.0)$ & $34(54.0)$ & $1.64(0.97-2.77)$ & & $1.47(0.86-2.52)$ & \\
\hline $\begin{array}{l}\text { Antibiotic prescriptions } \\
\text { supervised by a senior } \\
\text { physician }\end{array}$ & & & & 0.76 & & \\
\hline No & $84(34.9)$ & $158(65.1)$ & 1 & & & \\
\hline Yes & $133(36.0)$ & $237(64.0)$ & $1.05(0.75-1.48)$ & & & \\
\hline $\begin{array}{l}\text { Senior physician usually } \\
\text { compliant with guidelines }\end{array}$ & & & & 0.44 & & \\
\hline No & $82(37.4)$ & $137(62.6)$ & 1 & & & \\
\hline Yes & $135(34.4)$ & $258(65.6)$ & $0.87(0.62-1.23)$ & & & \\
\hline $\begin{array}{l}\text { Perceived level of education } \\
\text { on antibiotics }\end{array}$ & & & & 0.04 & & 0.04 \\
\hline Moderate/low & $40(28.2)$ & $102(71.8)$ & 1 & & 1 & \\
\hline High & 177 (37.7) & $293(62.3)$ & $1.54(1.02-2.32)$ & & $1.51(1.01-2.30)$ & \\
\hline
\end{tabular}


Table 3. Factors associated with appropriate practice on adverse events of antibiotic prescriptions

Tableau 3. Facteurs associés aux bonnes pratiques concernant les effets secondaires des prescriptions d'antibiotiques

\begin{tabular}{|c|c|c|c|c|c|c|}
\hline & $\begin{array}{l}\text { Appropriate } \\
\text { practice } \\
\mathrm{N}=245(39.4 \%) \\
\mathrm{n}(\%)\end{array}$ & $\begin{array}{l}\text { Inappropriate } \\
\text { practice } \\
\mathrm{N}=376(60.6 \%) \\
\mathrm{n}(\%)\end{array}$ & $\begin{array}{l}\text { Bivariate } \\
\text { regression } \\
\text { OR }(\mathrm{CI} 95 \%)\end{array}$ & $p$ & $\begin{array}{l}\text { Multivariable } \\
\text { regression } \\
\text { OR (CI 95\%) }\end{array}$ & $p$ \\
\hline Gender & & & & 0.07 & & 0.25 \\
\hline Male & $119(43.4)$ & $155(56.6)$ & 1 & & 1 & \\
\hline Female & $126(36.3)$ & $221(63.7)$ & $0.74(0.54-1.03)$ & & $0.82(0.58-1.15)$ & \\
\hline Year of specialisation & & & & 0.67 & & \\
\hline First year & $39(35.8)$ & $70(64.2)$ & 1 & & & \\
\hline Middle year(s) & $124(39.9)$ & $188(60.1)$ & $1.19(0.76-1.88)$ & & & \\
\hline Last year & $82(40.8)$ & $118(59.2)$ & $1.24(0.76-2.00)$ & & & \\
\hline Specialty & & & & 0.10 & & 0.09 \\
\hline Family medicine & $79(34.8)$ & $148(65.2)$ & 1 & & 1 & \\
\hline $\begin{array}{l}\text { Other medical } \\
\text { specialties }\end{array}$ & $122(42.4)$ & $166(57.6)$ & $1.38(0.96-1.97)$ & & $1.41(0.97-2.05)$ & \\
\hline Surgical specialties & $21(34.4)$ & $40(65.6)$ & $0.98(0.54-1.78)$ & & $1.08(0.58-1.99)$ & \\
\hline $\begin{array}{l}\text { Anesthesiology- } \\
\text { Intensive care }\end{array}$ & $23(51.1)$ & $22(48.9)$ & $1.96(1.03-3.73)$ & & $2.11(1.08-4.14)$ & \\
\hline $\begin{array}{l}\text { Frequency of antibiotic } \\
\text { prescribing } \\
<1 \text { prescription/day } \\
\geq 1 \text { prescription(s)/day }\end{array}$ & $\begin{array}{l}126(41.6) \\
119(37.4)\end{array}$ & $\begin{array}{l}177(58.4) \\
199(62.6)\end{array}$ & $\begin{array}{l}1 \\
0.84(0.61-1.16)\end{array}$ & 0.29 & & \\
\hline $\begin{array}{l}\text { Perceived level of } \\
\text { knowledge on } \\
\text { antibiotics }\end{array}$ & & & & $<0.001$ & & $<0.001$ \\
\hline Poor & $201(36.0)$ & $357(64.0)$ & 1 & & 1 & \\
\hline Good & $44(69.8)$ & $19(30.2)$ & $4.11(2.34-7.24)$ & & $3.71(2.09-6.61)$ & \\
\hline $\begin{array}{l}\text { Antibiotic prescriptions } \\
\text { supervised by a senior } \\
\text { physician }\end{array}$ & & & & 0.47 & & \\
\hline No & $102(41.2)$ & $145(58.8)$ & 1 & & & \\
\hline Yes & $143(38.3)$ & $231(61.7)$ & $0.89(0.64-1.23)$ & & & \\
\hline $\begin{array}{l}\text { Senior physician usually } \\
\text { compliant with } \\
\text { guidelines }\end{array}$ & & & & 0.12 & & 0.15 \\
\hline No & 79 (35.3) & $143(64.7)$ & 1 & & 1 & \\
\hline Yes & $166(41.6)$ & $233(58.4)$ & $1.31(0.93-1.84)$ & & $1.30(0.91-1.85)$ & \\
\hline $\begin{array}{l}\text { Perceived level of } \\
\text { education on antibiotics }\end{array}$ & & & & 0.005 & & 0.01 \\
\hline Moderate/low & $41(29.3)$ & 99 (70.7) & 1 & & 1 & \\
\hline High & $204(42.4)$ & $277(57.6)$ & $1.78(1.18-2.67)$ & & $1.70(1.11-2.58)$ & \\
\hline
\end{tabular}

